\title{
Assessing Resilience in Stressed Watersheds
}

\author{
$\underline{\text { Kristine T. Nemec }}^{1}, \underline{\text { Joana Chan }}^{2}, \underline{\text { Christina Hoffman }}^{2}, \underline{\text { Trisha L. Spanbauer }}^{3}, \underline{\text { Joseph A. Hamm }}^{4}, \underline{\text { Craig R. Allen }}^{5}, \underline{\text { Trevor Heflev }}^{2,6}$, \\ Donald Pan $^{7}$ and Prabhakar Shrestha ${ }^{2}$
}

\begin{abstract}
Although several frameworks for assessing the resilience of social-ecological systems (SESs) have been developed, some practitioners may not have sufficient time and information to conduct extensive resilience assessments. We have presented a simplified approach to resilience assessment that reviews the scientific, historical, and social literature to rate the resilience of an SES with respect to nine resilience properties: ecological variability, diversity, modularity, acknowledgement of slow variables, tight feedbacks, social capital, innovation, overlap in governance, and ecosystem services. We evaluated the effects of two large-scale projects, the construction of a major dam and the implementation of an ecosystem recovery program, on the resilience of the central Platte River SES (Nebraska, United States). We used this case study to identify the strengths and weaknesses of applying a simplified approach to resilience assessment. Although social resilience has increased steadily since the predam period for the central Platte River SES, ecological resilience was greatly reduced in the postdam period as compared to the predam and ecosystem recovery program time periods.
\end{abstract}

Key Words: ecological resilience; Platte River; resilience assessment; social-ecological system; social resilience

\section{INTRODUCTION}

River systems in water-stressed landscapes present some of the most challenging natural resource management issues facing the world today. Anthropogenic pressures have significantly altered river systems, affecting the provision of ecosystem services (Meybeck 2003). In addressing these challenges, resource managers often rely heavily on the resilience, or the capacity, of a social-ecological system (SES) to absorb and respond to a disturbance while maintaining its essential structure and functions (Holling 1973, Folke et al. 2002). An improved understanding of the boundaries of this resilience, i.e., the thresholds that separate one state of a system from alternative, possibly undesirable, states, may help resource managers avoid or facilitate regime shifts so that desired riverine ecosystem services are maintained or restored. Within the broader understanding of resilience, researchers have identified two subtypes, ecological and social resilience (Folke et al. 2002). Ecological resilience is the magnitude of disturbance that an ecosystem can absorb before it shifts into a new regime that is controlled by a different set of ecological processes (Holling and Gunderson 2002). Social resilience is the capacity of social systems, such as communities, to withstand and adapt to disturbances that result from social, political, or environmental changes (Adger 2000). Enhancing and maintaining resilience is increasingly identified as a management goal or strategy for projects focused on either ecosystems (e.g., Kareiva et al. 2008, Benson and Garmestani 2011, Sierra Club 2012, WWF 2012) or social systems (e.g., Godschalk 2003, Norris et al. 2008, Gwimbi 2009, Longstaff et al. 2010). However, a holistic systems approach to management that considers the components of both ecological and social resilience can be more effective in managing complex feedbacks and planning for change than treating resources as being entirely contained within either an ecosystem or a social system (Berkes and Folke 1998). Resource managers and scientists can develop strategies for coping with both known and unexpected changes by assessing the resilience of a linked SES (Resilience Alliance 2007, 2010). A resilience assessment that identifies key issues and system drivers and evaluates the past and current level of resilience (Walker et al. 2009, Resilience Alliance 2010) represents an important first step in holistically managing for a resilient system.

Although several frameworks have been proposed for conducting resilience assessments (e.g., Walker et al. 2002, 2009, Resilience Alliance 2007, 2010), the application of these techniques to realworld systems continues to be a challenge because of the highly dynamic and multidimensional nature of linked SESs (Berkes and Folke 1998, Walker et al. 2002). In addition, although some practitioners may find these or similar frameworks to be useful and appropriate (see Resilience Alliance 2013 for some case studies), others may want to conduct a resilience assessment but lack sufficient time or information to use the often detailed and time-consuming approaches inherent in existing frameworks. We present and apply a simplified approach to resilience assessment that incorporates Walker and Salt's (2006) nine measures of resilience: ecological variability, diversity, modularity, acknowledgement of slow variables, tight feedbacks, social capital, innovation, overlap in governance, and ecosystem services.

We apply the nine resilience metrics to evaluate the effects of two large-scale projects that have affected the SES of the central Platte River (Nebraska, United States). The projects include the construction of a $49 \mathrm{~m}$ tall, $5 \mathrm{~km}$ long earthen dam and the implementation of an ecosystem recovery program. Our assessment specifically focuses on three time periods: (1) from the European-American settlement of the Platte River region to the construction of Kingsley Dam and the filling of the Lake McConaughy reservoir, i.e., roughly mid-1800s to 1941; (2) after dam construction to before the implementation of the Platte River Recovery Implementation Program (PRRIP), i.e., 1941-2006; and (3) from the implementation of PRRIP to the present, i.e., 2007 to present. We provide a case study of the resilience of a diverse

${ }^{1}$ University of Nebraska-Lincoln, ${ }^{2}$ School of Natural Resources, University of Nebraska-Lincoln, ${ }^{3}$ Department of Earth and Atmospheric Sciences, University of Nebraska-Lincoln, ${ }^{4}$ Public Policy Center, University of Nebraska-Lincoln, ${ }^{5}$ U.S. Geological Survey Nebraska Cooperative Fish and Wildlife Research Unit, University of Nebraska-Lincoln, ${ }^{6}$ Department of Statistics, University of Nebraska-Lincoln, ${ }^{7}$ School of Biological Sciences, University of Nebraska-Lincoln 
SES, an understanding that is critical for effective management. We also present a framework for conducting a simplified resilience assessment that can be applied by scientists and managers in other SESs.

\section{Overview of the Platte River}

The Platte River is created by the junction of the North Platte and South Platte Rivers near the city of North Platte, Nebraska. Both the North Platte and South Platte Rivers originate in the Rocky Mountains in Colorado: The North Platte River flows north into Wyoming and then southeast into Nebraska, and the South Platte River flows northeast through Colorado into Nebraska. The Platte River generally flows eastward and joins the Missouri River at Plattsmouth, Nebraska.

The central Platte River, contained entirely within the state of Nebraska, supports a diversity of habitats and species. As of 1990, 409 bird species were documented along the central Platte, with 208 species known to have nested in the area at least once (Sidle and Faanes 1997). In addition, more than $86 \%$ of the world's Sandhill Crane (Grus canadensis) population uses the central Platte during migration (National Research Council 2004). Socially, the central Platte is used primarily for irrigation farming, hydroelectric energy production, and recreation (Eubanks et al. 1998, National Research Council 2004).

\section{HISTORY OF THE CENTRAL PLATTE RIVER SES}

\section{Prior to Kingsley Dam (before 1941)}

Historically, the central Platte was a sediment-rich river with a highly variable annual hydrograph (Hadley et al. 1987). Starting in the $1860 \mathrm{~s}$, canals were constructed to divert flows from the central Platte for irrigation (Eschner et al. 1983). In 1887, planning was initiated for Kingsley Dam, i.e., an effort to regulate the water in the river and bring additional hydroelectric power to rural Nebraska (Hamaker 1958). With the region experiencing drought during the 1890 s, the effort gained political momentum because a dam and reservoir would provide irrigation water for crops (Hamaker 1958). After numerous legislative failures and considerable debate over water rights and funding issues, U.S. Senator George Norris's support led to the project's funding by the Public Works Administration, and Kingsley Dam was completed in 1941 (Schaufelberger and Beck 2010).

\section{Kingsley Dam to creation of the PRRIP (1941-2006)}

The reservoir created by Kingsley Dam, Lake McConaughy, has a capacity of almost 2.5 billion $\mathrm{m}^{3}$ of storage water (CNPPID 2011). Operation of Kingsley Dam decreased variability in the hydrograph downstream of the impoundment, allowing a steady flow of water throughout the year (Fig. 1; Sidle and Faanes 1997). Although beneficial for irrigators and power production, the new flow regime altered the Platte River ecosystem by reducing or eliminating the number of scouring events that removed vegetation from sandbars and riverbanks and by trapping sediment that had previously created highly mobile sandbars (U. S. Department of the Interior 2006a). As a result of deteriorated and declining habitat, three bird species that depend on the Platte, the Interior Least Tern (Sternula antillarum athalassos), the Piping Plover (Charadrius melodus), and the Whooping Crane (Grus americana), and a fish species, the pallid sturgeon (Schaphirhynchus albus), were listed as threatened or endangered under the Endangered Species Act (ESA) or its predecessor, the
Endangered Species Preservation Act, between 1967 and 1990 (Freeman 2010).

Fig. 1. Median daily flows of the Platte River at Duncan, Nebraska, 69 km east of the central Platte River, in 1895-1909 and 1975-1998. Source: U.S. Department of the Interior (2006a).

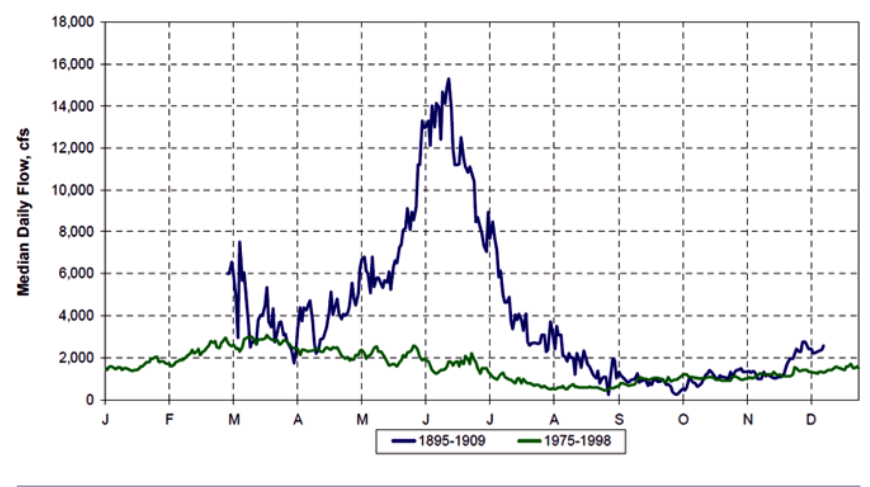

After creation of the PRRIP (2007 to present)

In 1994, the Kingsley Dam was required to petition for relicensing with the Federal Energy Regulatory Commission (FERC). The timing of FERC relicensing coincided with the willingness of Colorado, Wyoming, and Nebraska, the three states through which the Platte River flows, to address ESA concerns. These three states and the U.S. Department of the Interior ultimately developed an adaptive approach for managing the central Platte River by creating the PRRIP, established in 2007. The PRRIP's three main management objectives are to increase stream flow, restore habitat along the river, and use adaptive management to determine what habitat is required for endangered and threatened species (PRRIP 2012a).

\section{METHODS}

\section{Study area}

This resilience assessment is limited to the reach of the Platte River extending from Lake McConaughy on the North Platte River to Chapman, $\sim 327 \mathrm{~km}$ to the east of the lake. This region encompasses the 2 major projects that have affected the socialecological resilience of the central Platte River: the construction of Kingsley Dam and implementation of the PRRIP.

\section{Evaluation of resilience}

We reviewed the scientific, social, and historical literature relevant to the study area to determine whether the system in each of three time periods was resilient with respect to each of Walker and Salt's (2006) resilience characteristics. We also evaluated resilience for five components of the characteristic social capital as identified by the Social Capital Thematic Group, i.e., groups and networks, trust, collective action, social inclusion, and information and communication (The World Bank 2011), to create a composite score for social capital. Although social and ecological resilience are intertwined, we evaluated the properties for social and ecological resilience separately to provide a clearer assessment of the elements of resilience (Allen et al. 2003). Because not all of the properties applied to both kinds of resilience, we assessed eight 
with regard to social resilience and three for ecological resilience (Table 1). We concurred with Walker and Salt's (2006) creation of a property for ecological variability but not social variability because, as they defined it, variability refers to variability in the occurrence and magnitude of ecological phenomena such as flooding and wildfire that do not have a social equivalent. Similar aspects of a system such as social and cultural heterogeneity are incorporated into the social diversity and social modularity variables. Likewise, the social properties social capital, innovation, and overlapping governance do not have an ecological equivalent. We decided that the slow ecological variables themselves and tight ecological feedbacks are so closely related to ecological variability that these properties are encompassed by the ecological variability property, and ecosystem services are a social and not an ecological construct because they refer to the benefits that humans obtain from nature.

We used a rapid prototyping approach (Nicolson et al. 2002) to score the resilience of each property by having most of the authors individually rate each property on a scale of 1 to 5 , with 1 being least resilient and 5 being most resilient (Table 1). Additionally, we rated the uncertainty of each resilience score on a scale of 1 to 3 , i.e., low, medium, or high. Our individual rankings were influenced by expertise in our respective disciplines, which encompassed ecology, economics, geosciences, law psychology, molecular biology, social sciences, and statistics. To identify whether resilience scores changed over time, we calculated a mean resilience score for each criterion by computing the average of all the raters' individual scores $(n=8)$ across the 3 time periods. We then obtained $95 \%$ confidence intervals of the mean resilience score using the equal-tail percentiles from the nonparametric bootstrap sample of the mean using 100,000 bootstrap iterations (Efron and Tibshirani 1993, R Development Core Team 2007). We tested for significant differences in mean resilience scores across the 3 time periods by comparing the confidence intervals for each time period. If the confidence intervals overlapped, we concluded that the mean resilience scores were not significantly different (Gardner and Altman 1986). We then used the mode of our uncertainty estimates to create a collective assessment of uncertainty for each property.

\section{RESULTS}

\section{Ecological attributes}

\section{Ecological diversity}

The resilience score for ecological diversity was significantly higher in the predam period compared to the postdam period and the PRRIP period, reflecting human alterations to the Platte River channel that greatly reduced ecological diversity in the postdam time period, before rising slightly with implementation of the PRRIP (Table 2; Figs. 2, 3, and 4). Most scientific literature suggests that in the mid- to late 1800 s, the Platte was a braided river with limited trees along its banks and many areas of open, unvegetated channel containing numerous shifting sandbars (Currier and Davis 2000, National Research Council 2004, Horn et al. 2012). However, some scientists disagree, asserting that vegetated islands were common and riparian woodland was abundant along the Platte (Johnson and Boettcher 2000). In either case, the unregulated Platte was hydrologically connected to floodplain wetlands (Sidle and Faanes 1997), which created spatial and temporal heterogeneity in floodplain habitats that had the potential to support a high diversity of plants and animals (National Research Council 2004). Reduced peak flows resulting from Kingsley Dam significantly narrowed the width of the river downstream of the dam, reducing the number of mobile bare sandbars and increasing permanent riparian vegetation within the river channel (U.S. Department of the Interior 2006a, Horn et al. 2012).

Fig. 2. Resilience of the central Platte River social-ecological system in regard to Walker and Salt's (2006) nine resilience properties and level of uncertainty associated with each property during the time period before the Kingsley Dam.
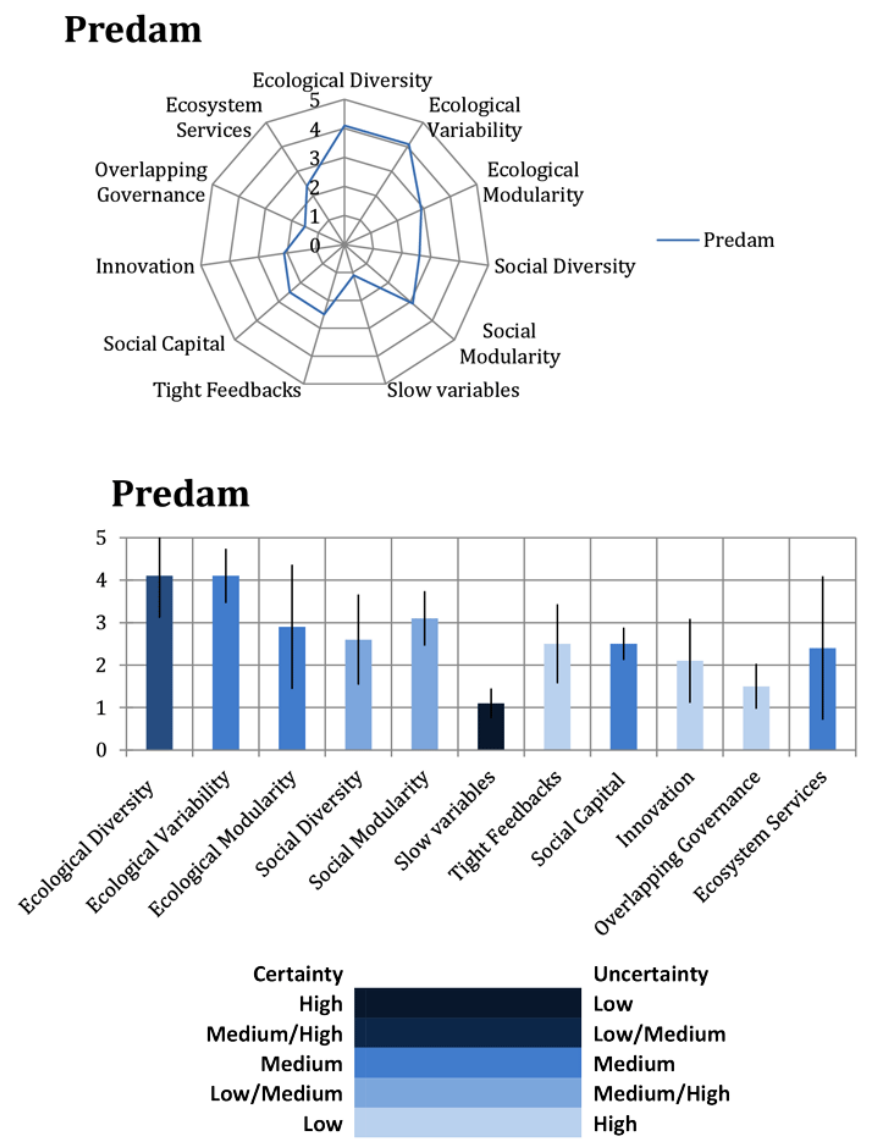

As of 2010, the PRRIP acquired 3,200 hectares of habitat complexes along the Platte that are being protected, restored, or maintained as habitat for Interior Least Terns, Piping Plovers, and Whooping Cranes (PRRIP 2009, 2010). However, because levels of habitat diversity in the postdam and PRRIP periods do not approach predam levels of habitat diversity, which likely included many thousands of hectares of open sandbar and shallow water habitat (U.S. Department of the Interior 2006b), the resilience score increased only slightly (Table 2). 
Table 1. Scoring system used for assessing the resilience of the central Platte River social-ecological system with respect to resilience properties described by Walker and Salt (2006). The system may exhibit resilience with respect to a property (5), not be resilient with respect to a property (1), be in a neutral condition that is not clearly exhibiting resilience or lacking resilience (3), or exhibit a level of resilience intermediate between these scores ( 2 or 4$)$.

\begin{tabular}{lll}
\hline \hline $\begin{array}{l}\text { Resilience } \\
\text { Property }\end{array}$ & Walter and Salt attributes & Score Categories \\
\hline 1. Diversity & "A resilient world would & Ecological \\
promote and sustain diversity in & $5=$ Large spatial and temporal heterogeneity in floodplain habitats (prairie, wet meadow, \\
all forms" (p. 145). & $\begin{array}{l}\text { wetland, riparian forest, sandbars). There is a high diversity of common, generalist species } \\
\text { as well as rarer, specialist species. } \\
\end{array}$ & $\begin{array}{l}3=\text { Some floodplain habitats replaced by monoculture crops, less unvegetated sandbars as } \\
\text { the river's flows are regulated. Populations of specialist species adapted to habitats }\end{array}$ \\
& $\begin{array}{l}\text { associated with varied river flows decline. } \\
1=\text { Many floodplain habitats are replaced by crops and very few unvegetated sandbars exist. } \\
\end{array}$ \\
& $\begin{array}{l}\text { Most plant and animal species are common, generalist species and specialist species } \\
\text { requiring sandbar habitat or variable flows are locally extinct or nearly locally extinct. }\end{array}$
\end{tabular}

Social

5 = Planning and decision-making processes incorporate a diverse array of stakeholder interests and perspectives and the social system maintains a diversity of livelihoods. $3=$ Few stakeholder groups, interests, and perspectives are incorporated into the planning and decision-making process. The social system is supported by a limited array of livelihoods.

$1=$ Decisions are made from the top down with little to no effort to incorporate stakeholder interests and/or perspectives. The social system lacks a diversity of livelihoods.

\section{Variability}

3. Modularity
"A resilient world would embrace and work with ecological variability" (p. 146).
Ecological variability of surface water hydrograph

$5=$ There is little to no regulation of the river system so there is large variability in the surface water hydrograph and there are periodic floods.

$3=$ The river system has been regulated to such an extent that variability in the surface water hydrograph has been reduced and floods are relatively uncommon.

$1=$ The river system has been regulated to such an extent that there is very little variability in the surface water hydrograph and floods are rare.

Social: Not applicable

"A resilient world would consist of modular components" (p. 146).

Ecological: subsystems are connected but not overly connected and disturbances do not cascade through the overall ecosystem

$5=$ The river is very loosely hydrologically connected to the groundwater table and floodplain habitats through periodic high river flows and floods.

$3=$ The river is less hydrologically connected to the groundwater table and floodplain because of uncommon flood events. Plant species adapted to drier conditions become more common in wetland and riparian forest habitats.

$1=$ The river is more hydrologically connected to the groundwater table and floodplain because of rare flood events and greatly reduced river flows. Plant species adapted to drier conditions are dominant in wetland and riparian forest habitats. Conversely, the river is overly connected to the groundwater table and floodplain because of common floods and high water flows. Large areas of vegetation either die or are inundated long enough that there are cascading effects through the ecosystem as wildlife are affected by the loss of vegetation.

Social: Implies the extent to which deleterious effects of perturbation to the system can be compartmentalized.

$5=$ Adequate avenues of communication and connectedness exist among stakeholders across vertical and horizontal scales; structure allows for meaningful and equitable communication throughout the system in which stakeholders are involved in the decisionmaking process and decisions are not handed down from above in a top-down bureaucratic approach. Connections are not so closely tied that one disturbance in the system ripples throughout the whole system.

$3=$ Limited avenues of communication and connectedness exist among stakeholders across vertical and/or horizontal scales; structure allows for some communication throughout the system but quality of communication may not be fully realized or equitable. Connections are not so closely tied that one disturbance in the system ripples throughout the whole system. $1=$ Avenues of communication and connectedness are nonexistent across scales and decisions are made independently of outside concerns or there are too many avenues of communication that lead to either a stalemate or disturbances travel quickly throughout the system with few barriers. 

4. Acknowledging
slow variables

5. Tight feedbacks

"A resilient world would posses tight feedbacks (but not too tight)" (p. 146)

6. Social capital

7. Innovation

8. Overlap in governance

9. Ecosystem services policy focus on 'slow, with thresholds" (p. 146).

"A resilient world would promote trust, well-developed (adaptability)" (p. 147).

"A resilient world would place an emphasis on learning, experimentation, locally developed rules, and embracing change" (p. 147).

"A resilient world would have 'redundancy' in their of common and private property with overlapping access rights" (p. 148).

all the unpriced ecosystem
"A resilient world would have a Ecological: Not applicable controlling variables associated Social: Management decisions acknowledge and address variables not always perceived by short-term observation.

$5=$ Slow variables are actively acknowledged and incorporated into the long-term governance of the social-ecological system.

$3=$ Slow variables are recognized to a limited extent but are not actively incorporated into the long-term governance of the social-ecological system.

$1=$ Slow variables are not acknowledged or incorporated into the long-term governance of the social-ecological system.

Social

5 = Experimentation, monitoring, and learning exist, increasing capacity to detect thresholds and to respond to change in a timely manner.

$3=$ Information is gathered about the system but this information is not organized or integrated in a timely manner into the decision-making process.

$1=$ Experimentation, monitoring, and learning are not incorporated into the decisionmaking process, resulting in a decreased capacity to detect thresholds and respond to change. social networks, and leadership Social: Goodwill that is earned by social interactions that can be used to facilitate action.

(Adler and Kwon 2002)

$5=$ The social system is supported by a high level of trust, well-developed social networks, and leadership, providing increased capacity to effectively and collectively respond to change.

$3=$ The social system is supported by a moderate level of trust, social networks, and leadership, providing limited capacity to effectively and collectively respond to change. $1=$ The social system lacks trust, social networks, and leadership, prohibiting effective and collective respond to change.

Social: Comparing the extent to which management regimes allow for experimentation and a diversity of activities.

$5=$ Learning and experimentation are actively incorporated into the decision-making process. Rules are locally developed and innovative changes are pursued and embraced. 3 = Learning and experimentation are not actively incorporated into the decision-making process. People are hesitant to accept innovation and change within the system.

$1=$ Learning, experimentation, and change are discouraged and incentives are in place that maintain the status quo. Ecological: Not applicable

Social: Redundancies in the functions of institutions that have decision-making power. governance structures and a mix $5=$ Institutions are flexible and include redundancy in their governance structures and there

is a mix of common and private property with overlapping access rights.

$3=$ Overlap in governance is weak. Property and access rights are not mixed or not clearly defined.

$1=$ Institutions are rigid and governed from the top down with no redundancy in roles.

Property and access rights are not mixed and/or not clearly defined.

"A resilient world would include Ecological: Not applicable services in development proposals and assessments" (p. 148).
Social: Comparison of how different management regimes account for routinely ignored services provided by the ecosystem. For example: erosion control; water quality. $5=$ Ecosystem services are recognized and given value in development proposals and assessments.

$3=$ There is a limited recognition of ecosystem services and they are not necessarily incorporated into the development process.

$1=$ Ecosystem services are not recognized or given value in the development process. 
Table 2. Mean $(n=8)$ scores for resilience and lower and upper confidence intervals for each of Walker and Salt's (2006) resilience properties as applied to the central Platte River social-ecological system. The confidence intervals were obtained using the equal-tail percentiles from the nonparametic bootstrap sample of the mean using 100,000 bootstrap iterations (Efron and Tibshirani 1993). Two means are significantly different if their confidence intervals do not overlap. PRRIP = Platte River Recovery Implementation Program.

\begin{tabular}{|c|c|c|c|c|c|c|c|c|c|}
\hline & \multicolumn{3}{|c|}{ Predam resilience } & \multicolumn{3}{|c|}{ Postdam resilience } & \multicolumn{3}{|c|}{ PRRIP resilience } \\
\hline & Mean & Lower CI & $\begin{array}{c}\text { Upper } \\
\text { CI }\end{array}$ & Mean & $\begin{array}{c}\text { Lower } \\
\text { CI }\end{array}$ & $\begin{array}{c}\text { Upper } \\
\text { CI }\end{array}$ & Mean & $\begin{array}{c}\text { Lower } \\
\text { CI }\end{array}$ & $\begin{array}{c}\text { Upper } \\
\text { CI }\end{array}$ \\
\hline \multicolumn{10}{|l|}{ Ecological Attributes } \\
\hline Ecological diversity & 4.125 & 3.375 & 4.625 & 2.5 & 2.125 & 2.875 & 2.625 & 2.0 & 3.25 \\
\hline Ecological variability & 4.125 & 3.75 & 4.5 & 1.5 & 1.125 & 2.0 & 1.875 & 1.5 & 2.25 \\
\hline Ecological modularity & 2.875 & 1.875 & 3.75 & 3.25 & 2.375 & 4.125 & 3.5 & 2.875 & 4.125 \\
\hline \multicolumn{10}{|l|}{ Social Attributes } \\
\hline Social diversity & 2.625 & 1.875 & 3.25 & 3.25 & 2.75 & 3.75 & 4.0 & 3.375 & 4.625 \\
\hline Social modularity & 3.125 & 2.75 & 3.5 & 3.0 & 2.625 & 3.375 & 3.125 & 2.625 & 3.625 \\
\hline Acknowledging slow variables & 1.125 & 1.0 & 1.375 & 2.0 & 1.5 & 2.5 & 3.125 & 2.75 & 3.5 \\
\hline Social tight feedbacks & 2.5 & 1.875 & 3.125 & 2.375 & 2.125 & 2.75 & 3.375 & 3.125 & 3.75 \\
\hline Social capital & 2.45 & 2.225 & 2.7 & 2.8 & 2.55 & 3.025 & 3.7875 & 3.65 & 3.9125 \\
\hline Innovation & 2.125 & 1.5 & 2.75 & 2.875 & 2.625 & 3.0 & 3.875 & 3.5 & 4.25 \\
\hline Overlapping governance & 1.5 & 1.125 & 1.875 & 3.0 & 2.625 & 3.375 & 3.75 & 3.25 & 4.25 \\
\hline Ecosystem services & 2.375 & 1.375 & 3.5 & 2.625 & 2.25 & 2.875 & 3.0 & 2.625 & 3.375 \\
\hline
\end{tabular}

Fig. 3. Resilience of the central Platte River social-ecological system in regard to Walker and Salt's (2006) nine resilience properties and level of uncertainty associated with each property during the time period after the Kingsley Dam.

\section{Postdam}

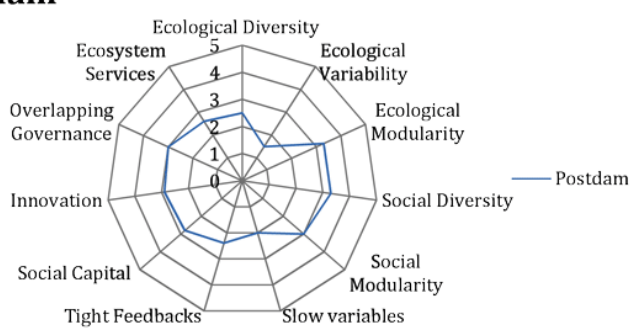

\section{Postdam}

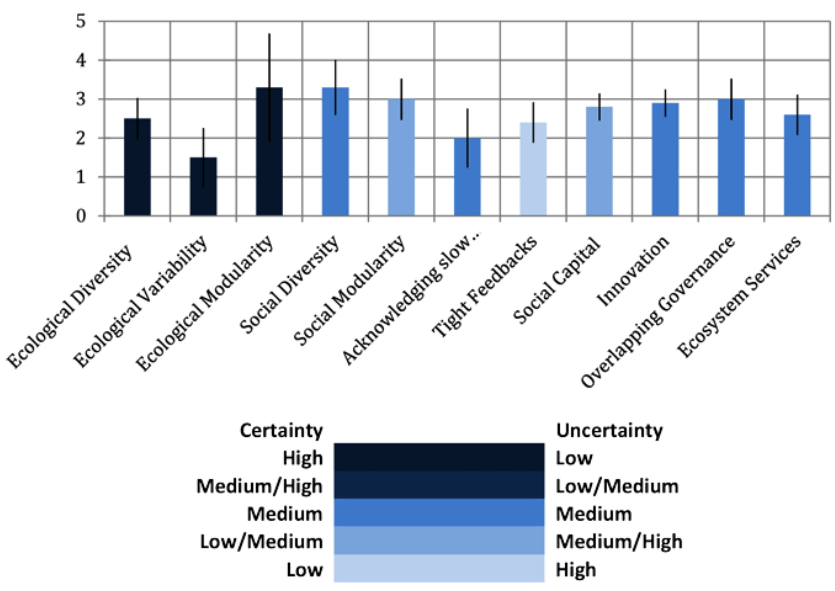

Fig. 4. Resilience of the central Platte River social-ecological system in regard to Walker and Salt's (2006) nine resilience properties and level of uncertainty associated with each property during the Platte River Recovery Implementation Program (PRRIP) time period.

\section{PRRIP}

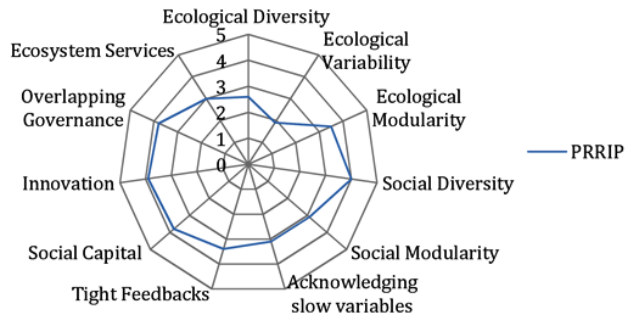

\section{PRRIP}

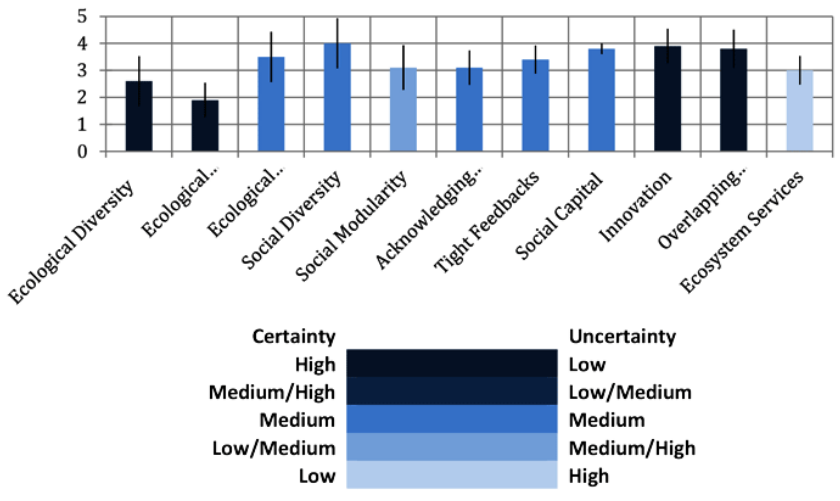




\section{Ecological variability}

As was the case for ecological diversity, the level of ecological variability was significantly higher for the predam period compared to the postdam and PRRIP time periods because of reduced variability in the river's hydrograph, although the score increased from the postdam to PRRIP time periods (Table 2; Figs. 2, 3, and 4). Prior to European-American settlement, there was large seasonal variation in the Platte River hydrograph, with peak flows in May and June and low base flows from August to March (Fig. 1; Sidle and Faanes 1997). Riparian wetlands were subject to flooding, and the morphology of river channels and islands shifted over time (Sidle and Faanes 1997). During the late 1800s, prior to dam construction, the river's hydrology was modified by extensive irrigation canals for agriculture (Eschner et al. 1983, Horn et al. 2012).

With the construction of the dam, the river's hydrograph substantially flattened: Spring peak flows were stored in the reservoir and released during the summer dry months (Fig. 1; National Research Council 2004). Although one of the stated objectives of the PRRIP is to increase the amount of water during historical spring peak flows, thereby enhancing the variability of the hydrograph, this objective has not yet been implemented in an ecologically meaningful way (PRRIP 2012c).

\section{Ecological modularity}

The mean resilience score for modularity gradually increased across the three time periods, but this change was not statistically significant (Table 2; Figs. 2, 3, and 4). Prior to the dam, modularity was created by the hydrologic connection of the groundwater table to floodplain wetlands, with the spatial and temporal mobility of the surface water facilitating loose connections among the river, groundwater table, and wetlands (U.S. Department of the Interior 2006a). Modularity increased after the dam was built because the surface water was confined to a narrower channel and was more disconnected from the floodplain, creating stronger internal connections among water and habitat within the channel and weakening connections between the channel and the floodplain. Modularity has changed little during the PRRIP time period because the PRRIP has not yet increased spring flows in the Platte, which may reduce modularity by improving connectivity among the Platte River, groundwater tables, and floodplain habitats.

\section{Social attributes}

\section{Social diversity}

Resilience of social diversity was significantly higher in the PRRIP time period compared to the predam time period, reflecting an increase in the variety of stakeholders involved in decision making (Table 2; Figs. 2 and 4). Increased social diversity increases the resilience of a system because it allows for a greater range of social backgrounds and potential ways of responding to disturbance. The proponents of the Tri-County project, which promised to bring irrigation water and hydropower to southcentral Nebraska, included prominent lawmakers and businesspeople (Hamaker 1958, Richter 2002). Most opposition to the project came from farmers who opposed bonds on the land and feared the costs of large public power and irrigation projects (Hamaker 1958). Although a diversity of stakeholder views and interests were voiced, shared decision making was limited (Hamaker 1958, Richter 2002).
Upon the construction of the dam, the newly impounded lakes and supply canals of the Tri-County project provided water for the development of agriculture and related industries. The creation of Lake McConaughy also spurred the establishment of wildlife and sports clubs, and a new tourism industry in Keith County served recreationists from as many as 20 different states (Richter 2002). Since the enactment of the PRRIP, agriculture has remained the dominant economic activity within the program area, and tourism continues based on the annual Sandhill Crane migration and recreational opportunities associated with the river and reservoir (CPNRD 2011).

\section{Social modularity}

Social modularity resilience scores changed little over time (Table 2; Figs. 2, 3, and 4). In the late 1800s, towns and farmsteads that were not along railroads were loosely connected by poorly maintained dirt roads that were often muddy and inaccessible, resulting in limited flows of information and communication throughout the system (Hudson 1985, Koster 1997, Weber 2005). Although road conditions and communication were improved in the 1920s following development of the Nebraska state highway system, Nebraska remained a largely rural state with loose connections between communities (Koster 1997, Weber 2005).

The Tri-County project further augmented road construction and rural electrification, facilitating communication (Hamaker 1958, Schaufelberger and Beck 2010). Although technological advances allow for more timely responses to weather changes and improved communication, closer ties between communities can also facilitate the transfer of shocks and disturbances throughout the system. A system has low modularity if social groups are so dependent on each other that the effects of a disturbance such as an economic crisis are rapidly transferred across the system, or if the system is at the other extreme and there are few avenues of communication among groups. Alternatively, a system is highly modular if components of the system have loose connections and a change in one component is not likely to strongly impact other groups. A highly modular system is also characterized by diversity in experiences and responses, and there is enough connectedness that social learning is facilitated both within and across groups (Janssen and Osnas 2005, Beilin et al. 2013). High modularity confers resilience to a system because loose communication among a diversity of social groups allows for greater adaptation to disturbance (Janssen and Osnas 2005, Beilin et al. 2013). Continuously improving communication technologies and increased stakeholder participation in the development of the PRRIP created tighter social connections within the Platte River community, yet the Platte River community consists of a diversity of groups from resource agencies to farmers to the nonfarming general public that maintain unique identities and avenues of communication separately from the PRRIP, slightly increasing modularity compared to the postdam period (Smith 2011).

\section{Acknowledging slow ecological variables}

Acknowledgement of slow ecological variables increased significantly over time, increasing resilience of the system (Table 2; Figs. 2, 3, and 4). In the central Platte, slow variables include river flows, island formation, plant community structure, sediment loading and nutrient dynamics, groundwater recharge and depletion, and accumulation of toxic chemicals in soils and groundwater. The variability of the hydrologic system was not 
acknowledged in the Tri-County project (Hamaker 1958, Richter 2002), and the control of hydrologic variability was primarily affected by the enactment of laws, thus reducing the ability of the system to acknowledge slow variables.

During the 1980s and 1990s, there was increased acknowledgement of slow ecological variables, such as groundwater levels, which was addressed in 1984 through legislation protecting instream flows and in 2004 through legislation requiring the Natural Resources Districts (NRDs) and the Nebraska Department of Natural Resources to be proactive in resolving conflicts between groundwater and surface water users (Stephenson 1993, Zuerlein 2007). The PRRIP incorporates experimentation and learning by applying an adaptive management approach to its recovery program (Smith 2011, PRRIP 2012b), recognizing that long-term ecological and social processes greatly influence ecosystem health. Although the program is making a concerted effort to apply adaptive management, experimentation and adaptation are often constrained by less flexible legal frameworks and a failure to address slow variables in management actions.

\section{Social tight feedbacks}

Resilience through social tight feedbacks significantly increased from the postdam time period to the PRRIP time period (Table 2; Figs. 3 and 4). In the early 1930s, many farmers abandoned their fields because of poor crop production attributable to drought and erosion (Peters et al. 2007). Eventually, a threshold was crossed, which caused erosion to spread and become common among fields and then across landscapes (Peters et al. 2007). Farmers had difficulty adjusting to these tightened ecological feedbacks because of loose social feedbacks that did not facilitate a coordinated response to drought, until the formation of soil conservation districts in 1937 (Hansen and Libecap 2004). Within the central Platte River region, however, it appears that some farmers adapted to drought by either diverting water from the Platte River into canals or accessing groundwater through irrigation wells (Hamaker 1958). Considering the presence of both loose and tight feedbacks during the Dust Bowl, resilience was low during the predam time period.

In the postdam time period, information feedbacks that allowed farmers to hear about changes in weather and markets increased with rural electrification. Storage lakes and irrigation canals also loosened ecological feedbacks for farming communities. In the long term, ready access to irrigation water, regardless of environmental conditions, such as drought, creates looser feedbacks between ecological changes and the social capacity to adapt to such shocks. The scientific research and educational components of the PRRIP promote learning and heightened awareness of how human actions interact with nature, affording stakeholders a better understanding of how complex feedback loops impact the system and increasing resilience relative to the earlier time periods (Smith 2011).

\section{Social capital}

Social capital showed the same pattern as social tight feedbacks, increasing significantly from the postdam to PRRIP time periods (Table 2; Figs. 3 and 4). Strong leadership is evident predam when numerous groups worked toward the common goal of bringing public power and irrigation to rural Nebraska. However, as evidenced by protests and farmers' concerns over bonds on their land, there was little trust of the leadership of the Tri-County project (Hamaker 1958).

After the dam, rural electrification facilitated increased communication, leading to greater potential for the creation of strong social networks. Project-related irrigation efforts, however, facilitated farm consolidation, which in turn reduced community sizes and hampered the development of social infrastructure (Schafer 1993, Hiller et al. 2009). Social capital increased during the PRRIP time period because the PRRIP's current governance committee consists of representatives from the three partner states, the U.S. Bureau of Reclamation, the U.S. Fish and Wildlife Service, water users, and environmental groups (Smith 2011). The resulting social network connects each of the individual groups and interests represented, allowing for regular face-to-face communication.

\section{Innovation}

The resilience score for innovation increased with each time period, and the difference between the postdam and PRRIP time periods was significant (Table 2; Figs. 2, 3, and 4). Water shortages in the predam central Platte River led to widespread irrigation experimentation, such as subsoil storage of water and farming without supplemental water (Hamaker 1958). However, the drive to acquire rural public power resulted in stifled experimentation and learning by encouraging reliance on irrigation water from canals.

Nebraska's creation of 23 NRDs in 1972 was a novel way to locally govern water resources based on watershed boundaries, increasing the score for innovation (NARD 2011). However, because innovation tends to be positively correlated with population density and size (Ernstson et al. 2010), depopulation of rural Nebraska during this time also hindered innovation to some extent.

The score for innovation was highest in the PRRIP time period because the PRRIP is currently involved in a number of innovative experiments that evaluate habitat requirements for threatened and endangered species along the river (PRRIP 2010, 2012b). Although these programs are based on the concept of adaptive management, experimentation is often constrained by the legal framework currently in place within the state. For example, most of the rivers and streams in Nebraska are already fully or overappropriated, making water available for experimental use limited and often difficult and expensive to obtain.

\section{Overlapping governance}

Overlapping governance significantly increased in resilience from the predam to postdam time periods, with a smaller increase from the postdam to PRRIP time periods (Table 2; Figs. 2, 3, and 4). Predam, local organizations and later state and federal government all worked toward establishing and creating a public power and irrigation project on the Platte River (Hamaker 1958). This shows a cooperative redundancy in the governance of the Tri-County project. However, land was either common property or private property, and there was no mention of overlapping access rights for this era (Hamaker 1958).

Postdam, there was a large increase in overlapping governance of water resources along the central Platte. Several agencies, i.e., the Central Nebraska Public Power and Irrigation District, Nebraska Game and Parks Commission, state NRDs, and the U.S. Fish and 
Wildlife Service, became involved in managing water resources (Zuerlein 2007, Freeman 2010). The PRRIP is managed by a governance committee that includes federal, state, and local representatives, allowing multiple levels of governance to work collectively on the management of the program (Smith 2011). However, the PRRIP governance committee must also work within the divided governance structure in place within Nebraska because of the state's separate institutions for managing groundwater and surface water.

\section{Ecosystem services}

The resilience score for the provision of ecosystem services steadily increased over time, although the increase was not statistically significant (Table 2; Figs. 2, 3, and 4). The ecosystem services provided by soil were recognized with passage of the Soil and Conservation Domestic Allotment Act of 1936, which paid farmers to reduce production to conserve soil. However, no other major law or act was passed during the Tri-County project that included unpriced ecosystem services, nor did any developmental proposals or assessments take ecosystem services into account (Hamaker 1958).

Recognition of ecosystem services, such as food production, biodiversity, and water-related recreation opportunities on Lake McConaughy (Richter 2002, Zuerlein 2007), increased postdam. These advances, however, were overshadowed by larger trends toward the overappropriation of surface water and groundwater for irrigation, and the degradation of water quality from agricultural intensification and runoff (Frenzel et al. 1998, Freeman 2010). Although water within the area is highly valued for irrigation and hydroelectric generation, the benefits that water and species provide for the larger ecosystem continue to be largely unrecognized in the PRRIP time period (Freeman 2010).

\section{DISCUSSION}

Although social resilience has increased steadily since the predam period for the central Platte River SES, ecological resilience was greatly reduced in the postdam period as compared to the predam and PRIPP time periods (Fig. 5). The creation of environmental laws and agencies later on in the postdam era improved social resilience by providing overlapping governance of water resources in the state, and social resilience has also been improved somewhat by completion of the PRRIP, which incorporates stakeholder involvement. Although the PRRIP attempts to reverse some of the negative ecological impacts and enhance connectivity in the system, these changes are highly engineered and small in scale relative to the greater system. Proposed restoration efforts, such as sand island building, require considerable resources. Whereas hydrologic processes related to flooding influenced the Platte River before the dam, it is now more strongly influenced by engineered processes. Thus, improvements to the system's resilience are presently small. Although this analysis has shown that the social and ecological systems are likely to be very interrelated, the fact that they do not necessarily move together lends credence to the argument that both kinds of resilience must be explicitly considered to understand the resilience of an SES. We applied each of Walker and Salt's principles individually, but the overall resilience of an SES is an emergent systems property, which must be considered holistically. By definition, emergent properties are greater than or at least different from the sum of their individual parts. We found cobweb diagrams (Figs. 2, 3, 4, and 6) to be useful for providing a holistic visual depiction of the resilience of a system. We acknowledge that some variables are inherently related and will either increase or decrease concurrently. For example, systems with high ecological variability will provide appropriate habitat and other resources for a greater variety of species than systems with low ecological variability. A social system with tight feedbacks will allow innovation to be rapidly distributed but will also allow disturbance to move quickly through the system. It is useful to examine all of the variables as a whole through cobweb diagrams and separately in the text of a resilience assessment both to better understand the overall resilience of the system and to help identify which variables could be managed to influence other variables and provide the desired level of resilience for the system. In addition, the variables that are most important for conferring resilience may vary within each SES. For example, within the Platte River SES, economic variability in the river's flows and overlapping governance are particularly important for the system's resilience.

Fig. 5. Social and ecological resilience of the central Platte River social-ecological system over the predam, postdam, and Platte River Recovery Implementation Program time periods, as described by summed resilience scores for all of the social and ecological resilience properties.

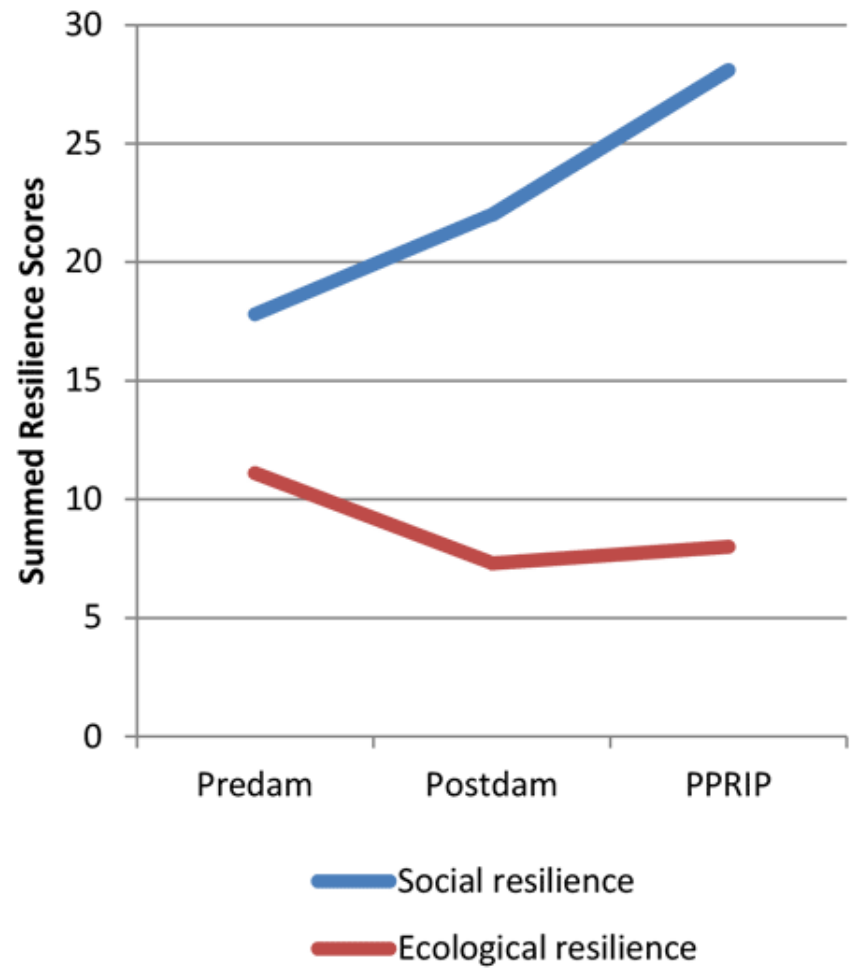

Overall, our approach to resilience assessment presents a relatively rapid, simplified approach that may appeal to practitioners, decision makers, and scientists who do not have the time and resources to conduct a more detailed resilience assessment. It relies on a search of scientific, social, and historical 
literature to characterize the resilience of an SES before and after major disturbances and can help generate discussion about ways to increase the resilience of the system. While conducting our assessment, we identified several strengths and limitations to this approach that influence the ability to understand the resilience of both the Platte River SES and SESs in general.

Fig. 6. Animation of changes in the resilience of the central Platte River social-ecological system over three time periods: (a) before the Kingsley Dam, (b) after the Kingsley Dam, and (c) during the Platte River Recovery Implementation Program.

The animation can be viewed online. Please visit: http://www.ecologyandsociety.org/vol19/iss 1/art34/figure6.html

Walker and Salt (2006) listed nine properties that contribute to resilience: variability, diversity, modularity, acknowledgement of slow variables, tight feedbacks, social capital, innovation, overlap in governance, and ecosystem services. Because most of these properties are described in terms of social resilience, we had only three ecological resilience properties to evaluate, i.e., variability, diversity, and modularity, compared with eight social resilience properties, i.e., diversity, modularity, acknowledgement of slow variables, tight feedbacks, social capital, innovation, overlap in governance, and ecosystem services.

We found some variables easier to assess than others, either because there was sufficient data or because the variable was clearly defined. In general, less uncertainty was associated with ecological resilience variables because of the greater ease in quantifying many ecological variables compared with social resilience variables. For example, the level of ecological variability in the Platte River system can be clearly identified for the $1900 \mathrm{~s}$ because hydrographs have been constructed based on flow data during this time period. Although flow levels can be quantified, there remains inherent uncertainty in the dynamics of rivers with highly variable flows that can confer resilience to the system. For some properties, the relative status of the variable can be inferred from the available data even if there is not much quantitative data. The level of ecological diversity can be inferred based on the heterogeneity of habitats within the floodplain and the relative abundance of invasive, aggressive species and threatened and endangered species. Social diversity can be assessed by considering the number of stakeholder groups and the presence or absence of mechanisms for stakeholders to participate in decision making and planning. Uncertainty for innovation and overlapping governance steadily decreased over all three time periods because the creation of NRDs in the postdam period and the PRRIP were readily associated with increased experimentation and approaches to resource management, as well as increased overlapping governance of natural resources.

Other properties were more difficult to assess and were associated with greater uncertainty because of a lack of information or because the variable has not been clearly defined. Changes in social characteristics were more subtle and not as well documented in the literature as ecological variables, particularly for the predam time period. Some variables also have more subjective definitions than others. For example, in assessing modularity, there is no defined method for measuring how the human connections within a system positively, negatively, or synergistically influence the system. Another factor that has not been well defined is tight feedback loops in application to the social resilience of a system. In this assessment, we characterized feedback loops to incorporate both experiential and technological knowledge within the social system. However, understanding human use of this knowledge and how it feeds back into the system requires a much more in-depth qualitative analysis than provided in this initial assessment. Measuring the influence of slow variables on a social system also requires insight into how humans view the system and the extent to which people within the system recognize long-term social and ecological processes. Within the Platte River system, awareness of slow variables has increased through time; however, the extent to which these variables are understood and considered in management decisions is less clear.

\section{CONCLUSION}

Practitioners typically have limited time and resources for conducting monitoring or evaluation because funding priorities often focus on project implementation. Our simplified approach for resilience assessment can be useful for generating discussion and identifying what characterizes resilience in a system. Although resilience is conceptually an emergent property, by breaking it down into nine components managers can identify those components that they are better able to influence. We underscored the importance of and problems regarding the uncertainty inherent in work like this, in part because of the subjective nature of determining resilience. Some of this uncertainty is the result of insufficient measurement and can be reduced, but some is the result of human limitations. Without an ability to see the future and with limited data about the past, uncertainty will always be an important factor in assessments like these.

Responses to this article can be read online at: http://www.ecologyandsociety.org/issues/responses. $\mathrm{php} / 6156$

\footnotetext{
Acknowledgments:

The Nebraska Cooperative Fish and Wildlife Research Unit is jointly supported by a cooperative agreement between the U.S. Geological Survey, the Nebraska Game and Parks Commission, the University of Nebraska-Lincoln, the U.S. Fish and Wildlife Service, and the Wildlife Management Institute. K. T. Nemec, J. Chan, C. Hoffman, T. L. Spanbauer, J. A. Hamm, T. Hefley, and D. Pan received support through the NSF IGERT on Resilience and Adaptive Governance of Stressed Watersheds at the University of Nebraska-Lincoln (NSF \# 0903469). Earlier versions of this manuscript were improved by comments from Sheri Fritz and input from Leo Acosta, Sarah Becker, Corinne Kolm, and Sergio Rico. We thank Kerry Hart for designing an interactive graphic displaying changes in the resilience of the Platte River SES over time.
} 


\section{LITERATURE CITED}

Adger, W. N. 2000. Social and ecological resilience: are they related? Progress in Human Geography 24:347-364.

Adler, P. S., and S.-W. Kwon. 2002. Social capital: prospects for a new concept. Academy of Management Review 27:17-40. http:// dx.doi.org/10.2307/4134367

Allen, T. F. H., J. A. Tainter, and T. Hoekstra. 2003. Supply-side sustainability. Columbia University Press, New York, New York, USA.

Beilin, R., N. T. Reichelt, B. J. King, A. Long, and S. Cam. 2013. Transition landscapes and social networks: examining on-ground community resilience and its implications for policy settings in multiscalar systems. Ecology and Society 18(2): 30. http://dx.doi. org/10.5751/ES-05360-180230

Benson, M. H., and A. S. Garmestani. 2011. Can we manage for resilience? The integration of resilience thinking into natural resource management in the United States. Environmental Management 48:392-399. http://dx.doi.org/10.1007/s00267-011-9693-5

Berkes, F., and C. Folke. 1998. Linking social and ecological systems for resilience and sustainability. Pages 1-25 in F. Berkes and C. Folke, editors. Linking social and ecological systems: management practices and social mechanisms for building resilience. Cambridge University Press, New York, New York, USA.

Central Nebraska Public Power and Irrigation District (CNPPID). 2011. Operations of the central district. CNPPID, Holdrege, Nebraska, USA. [online] URL: http://www.cnppid. com/Operations.htm

Central Platte Natural Resources District (CPNRD). 2011. Master plan 2011. CPNRD, Grand Island, Nebraska, USA. [online] URL: http://www.cpnrd.org/MasterPlan\%202011-2021\% 20Final.pdf

Currier, P. J., and C. A. Davis. 2000. The Platte as a prairie river: a response to Johnson and Boettcher. Great Plains Research 10:69-84.

Efron, B., and R. J. Tibshirani. 1993. An introduction to the bootstrap. Chapman and Hall/CRC, Boca Raton, Florida, USA.

Ernstson, H., S. E. van der Leeuw, C. L. Redman, D. J. Meffert, G. Davis, C. Alfsen, and T. Elmqvist. 2010. Urban transitions: on urban resilience and human-dominated ecosystems. Ambio 39:531-545. http://dx.doi.org/10.1007/s13280-010-0081-9

Eschner, T. R., R. F. Hadley, and K. D. Crowley. 1983. Hydrologic and morphologic changes in channels of the Platte River Basin in Colorado, Wyoming, and Nebraska: a historical perspective. Geological Survey Professional Paper 1277-A, U.S. Government Printing Office, Washington, D.C., USA.

Eubanks, T. L., Jr., R. B. Ditton, and J. R. Stoll. 1998. Platte River nature recreation study: the economic impact of wildlife watching on the Platte River in Nebraska. Prepared for the U.S. Environmental Protection Agency, Region VII, by Fermata Inc., Austin, Texas, USA.

Folke, C., S. Carpenter, T. Elmqvist, L. Gunderson, C. S. Holling, B. Walker, J. Bengtsson, F. Berkes, J. Colding, K. Danell, M.
Falkenmark, L. Gordon, R. Kasperson, N. Kautsky, A. Kinzig, S. Levin, K.-G. Mäler, F. Moberg, L. Ohlsson, P. Olsson, E. Ostrom, W. Reid, J. Rockström, H. Savenije, and U. Svedin. 2002. Resilience and sustainable development: building adaptive capacity in a world of transformations. Scientific Background Paper on Resilience for the process of the World Summit on Sustainable Development on behalf of the Environmental Advisory Council to the Swedish Government, Stockholm, Sweden, and International Council for Scientific Unions (ICSU) Series on Science for Sustainable Development No. 3, ICSU, Paris, France.

Freeman, D. M. 2010. Implementing the Endangered Species Act on the Platte Basin water commons. University Press of Colorado, Boulder, Colorado, USA.

Frenzel, S. A., R. B. Swanson, T. L. Huntzinger, J. K. Stamer, P. J. Emmons, and R. B. Zelt. 1998. Water quality in the central Nebraska basins, Nebraska, 1992-95. U.S. Geological Survey Circular 1163, U.S. Geological Survey, Reston, Virginia, USA [online] URL: http://water.usgs.gov/pubs/circ1163

Gardner, M. J., and D. G. Altman. 1986. Confidence intervals rather than P values: estimation rather than hypothesis testing. British Medical Journal 292:746-750. http://dx.doi.org/10.1136/ bmj.292.6522.746

Godschalk, D. R. 2003. Urban hazard mitigation: creating resilient cities. Natural Hazards Review 4:136-143. http://dx.doi. org/10.1061/(ASCE)1527-6988(2003)4:3(136)

Gwimbi, P. 2009. Linking rural community livelihoods to resilience building in flood risk reduction in Zimbabwe. Jàmbá: Journal of Disaster Risk Studies 2(1):71-79. http://dx.doi. org/10.4102/jamba.v2i1.16

Hadley, R. F., M. R. Karlinger, A. W. Burns, and T. R. Eschner. 1987. Water development and associated hydrologic changes in the Platte River, Nebraska, U.S.A. Regulated Rivers: Research and Management 1(4):331-341. http://dx.doi.org/10.1002/rrr.3450010405

Hamaker, G. E. 1958. Irrigation pioneers: a history of the TriCounty project to 1935. Dissertation. University of NebraskaLincoln, Lincoln, Nebraska, USA.

Hansen, Z. K., and G. D. Libecap. 2004. Small farms, externalities, and the Dust Bowl of the 1930s. Journal of Political Economy 112:665-694. http://dx.doi.org/10.1086/383102

Hiller, T. L., L. A. Powell, T. D. McCoy, and J. J. Lusk. 2009. Long-term agricultural land-use trends in Nebraska, 1866-2007. Great Plains Research 19:225-237.

Holling, C. S. 1973. Resilience and stability of ecological systems. Annual Review of Ecology and Systematics 4:1-23. http://dx.doi. org/10.1146/annurev.es.04.110173.000245

Holling, C. S., and L. H. Gunderson. 2002. Resilience and adaptive cycles. Pages 25-62 in L. H. Gunderson and C. S. Holling, editors. Panarchy: understanding transformations in human and natural systems. Island, Washington, D.C., USA.

Horn, J. D., R. M. Joeckel, and C. R. Fielding. 2012. Progressive abandonment and planform changes of the central Platte River in Nebraska, central USA, over historical timeframes. Geomorphology 139-140:372-383. http://dx.doi.org/10.1016/j. geomorph.2011.11.003 
Hudson, J. C. 1985. Plains country towns. University of Minnesota Press, Minneapolis, Minnesota, USA.

Janssen, M. A., and E. E. Osnas. 2005. Adaptive capacity of social-ecological systems: lessons from immune systems. EcoHealth 2:93-101. http://dx.doi.org/10.1007/s10393-004-0158-7

Johnson, W. C., and S. E. Boettcher. 2000. The pre-settlement Platte: wooded or prairie river? Great Plains Research 10:39-68.

Kareiva, P., C. Enquist, A. Johnson, S. H. Julius, J. Lawler, B. Petersen, L. Pitelka, R. Shaw, and J. M. West. 2008. Synthesis and conclusions. Pages 9-1 to 9-66 in S. H. Julius and J. M. West, editors. Preliminary review of adaptation options for climatesensitive ecosystems and resources. Final report, Synthesis and Assessment Product 4.4, U.S. Climate Change Science Program and the Subcommittee on Global Change Research, U.S. Environmental Protection Agency, Washington, D.C., USA.

Koster, G. E. 1997. A story of highway development in Nebraska. Department of Roads, Lincoln, Nebraska, USA. [online] URL: http://www.dor.state.ne.us/history/docs/history-general.pdf

Longstaff, P. H., N. J. Armstrong, K. Perrin, W. M. Parker, and M. A. Hidek. 2010. Resilient communities: a preliminary framework. Homeland Security Affairs VI(3):1-23.

Meybeck, M. 2003. Global analysis of river systems: from Earth system controls to Anthropocene syndromes. Philosophical Transactions of the Royal Society B 358(1440):1935-1955. http:// dx.doi.org/10.1098/rstb.2003.1379

National Research Council. 2004. Endangered and threatened species of the Platte River. National Academies, Washington, D. C., USA.

Nebraska Association of Resources Districts (NARD). 2011. About NARD. NARD, Lincoln, Nebraska, USA. [online] URL: http://nrdnet.org/overview.php

Nicolson, C. R., A. M. Starfield, G.P . Kofinas, and J. A. Kruse. 2002. Ten heuristics for interdisciplinary modeling projects. Ecosystems 5:376-384. http://dx.doi.org/10.1007/s10021-001-0081-5

Norris, F. H., S. P. Stevens, B. Pfefferbaum, K. F. Wyche, and R. L. Pfefferbaum. 2008. Community resilience as a metaphor, theory, set of capacities, and strategy for disaster readiness. American Journal of Community Psychology 41:127-150. http:// dx.doi.org/10.1007/s10464-007-9156-6

Peters, D. P. C., O. E. Sala, C. D. Allen, A. Covich, and M. Brunson. 2007. Cascading events in linked ecological and socioeconomic systems. Frontiers in Ecology and the Environment 5:221-224. http://dx.doi.org/10.1890/1540-9295(2007)5[221: CEILEA]2.0.CO;2

Platte River Recovery Implementation Program (PRRIP). 2009. The land plan and land acquisition. Fact Sheet, PRRIP, Kearney, Nebraska, USA. [online] URL: http://www.platteriverprogram. org/News/Documents/Land $\% 20$ Fact $\% 20$ Sheet.pdf

Platte River Recovery Implementation Program (PRRIP). 2010. Bi-annual report, 2009 and 2010. PRRIP, Kearney, Nebraska, USA. [online] URL: http://www.platteriverprogram.org/PubsAndData/ ProgramLibrary/PRRIP\%20BiAnnual\%20Report\%202009-2010. pdf
Platte River Recovery Implementation Program (PRRIP). $2012 a$. Platte River Recovery Implementation Program. PRRIP, Kearney, Nebraska, USA. [online] URL: http://www.platteriverprogram. org/Pages/default.aspx

Platte River Recovery Implementation Program (PRRIP). $2012 b$. Platte River Recovery Implementation Program: adaptive management. PRRIP, Kearney, Nebraska, USA. [online] URL: http://www.platteriverprogram.org/AboutPRRIP/Pages/

AdaptiveManagement.aspx

Platte River Recovery Implementation Program (PRRIP). 2012c. Platte River Recovery Implementation Program: water plan. PRRIP, Kearney, Nebraska, USA. [online] URL: http://www. platteriverprogram.org/AboutPRRIP/Pages/WaterPlan.aspx

R Development Core Team. 2007. R: a language and environment for statistical computing. R Foundation for Statistical Computing, Vienna, Austria.

Resilience Alliance. 2007. Assessing resilience in social-ecological systems: a workbook for scientists. Version 1.1. [online] URL: http://www.seachangecop.org/sites/default/files/documents/2007\% 2006\%20RA $\% 20$ assesing $\% 20$ Resilience $\% 20$ in $\% 20$ SES $\% 20-\% 20$ Scientists $\%$ 20Workbook.pdf

Resilience Alliance. 2010. Assessing resilience in social-ecological systems: workbook for practitioners. Version 2.0. [online] URL: http://www.resalliance.org/index.php/resilience assessment

Resilience Alliance. 2013. Resilience assessment projects database. [online] URL: http://www.resalliance.org/cdirs/raprojects/index. php

Richter, R. 2002. Lake McConaughy: a geographic portrait. Keith County News, Ogallala, Nebraska, USA.

Schafer, S. 1993. Economics and finance. Pages 113-131 in C. A. Flowerday, editor. Flat water: a history of Nebraska and its water. Conservation and Survey Division, Institute of Agriculture and Natural Resources, University of Nebraska-Lincoln, Lincoln, Nebraska, USA.

Schaufelberger D., and B. Beck. 2010. The only state: a history of public power in Nebraska. Walsworth, Virginia Beach, Virginia, USA.

Sidle, J. G., and C. A. Faanes. 1997. Platte River ecosystem resources and management, with emphasis on the Big Bend reach in Nebraska. U.S. Fish and Wildlife Service, Grand Island, Nebraska; Northern Prairie Wildlife Research Center Online, Jamestown, North Dakota, USA. [online] URL: http://www. npwrc.usgs.gov/resource/habitat/plrivmgt/index.htm

Sierra Club. 2012. Resilient habitats: protecting 10 vulnerable ecosystems from climate change. Sierra Club, San Francisco, California, USA. [online] URL: http://www.sierraclub.org/ habitat/ecosystems/

Smith, C. B. 2011. Adaptive management on the central Platte River - science, engineering, and decision analysis to assist in the recovery of four species. Journal of Environmental Management 92:1414-1419. http://dx.doi.org/10.1016/j.jenvman.2010.10.013 
Stephenson, K. 1993. Groundwater management in Nebraska: governing the commons through local resource districts. Natural Resource Journal 36:761-778.

U.S. Department of the Interior. 2006a. Platte River Recovery Implementation Program: final environmental impact statement. Summary, three volumes. Platte River EIS Office, Denver, Colorado, USA.

U.S. Department of the Interior. 2006b. Record of decision: Platte River Recovery Implementation Program. U.S. Department of the Interior, Washington, D.C., USA.

Walker, B. H., N. Abel, J. M. Anderies, and P. Ryan. 2009. Resilience, adaptability, and transformability in the GoulburnBroken Catchment, Australia. Ecology and Society 14(1): 12. [online] URL: http://www.ecologyandsociety.org/vol14/iss1/ $\underline{\operatorname{art} 121}$

Walker, B., S. Carpenter, J. Anderies, N. Abel, G. S. Cumming, M. Janssen, L. Lebel, J. Norberg, G. D. Peterson, and R. Pritchard. 2002. Resilience management in social-ecological systems: a working hypothesis for a participatory approach. Conservation Ecology 6(1): 14. [online] URL: http://www. consecol.org/vol6/iss1/art14

Walker, B., and D. Salt. 2006. Resilience thinking: sustaining ecosystems and people in a changing world. Island, Washington, D.C., USA.

Weber, J. 2005. The morphogenesis of state highway networks in the United States. Journal of Historical Geography 31:723-743. http://dx.doi.org/10.1016/j.jhg.2004.11.001

The World Bank. 2011. Overview: social capital. The World Bank, Washington, D.C., USA. [online] URL: http://go.worldbank.org/ C0OTRW4QF0

World Wildlife Fund (WWF). 2012. Resilience-building: a new approach to protecting Arctic ecological values. WWF Global Arctic Programme, Ottawa, Ontario, Canada. [online] URL: http://wwf.panda.org/who_we are/wwf_offices/denmark/index.cfm? $\underline{\text { uProjectID }=9 \mathrm{Z} 1414}$

Zuerlein, G. 2007. Remember our rivers! An overview of instream flows in Nebraska. Prairie Fire, August. [online] URL: http:// www.prairiefirenewspaper.com/2007/08/remember-our-rivers 